\title{
Article \\ Effect of calf starter on the growth performance of dairy calves
}

Rezaul Mahmud Nahid ${ }^{1 *}$, Md. Anwar Hossain ${ }^{2}$, Mst. Latifa Yesmin Camy ${ }^{3}$, Md. Rakibul Hasan ${ }^{4}$, Shuvendu Sarkar ${ }^{4}$, Golam Sagir Ahammad ${ }^{5}$, Md. Hafizur Rahman ${ }^{4}$, Mohammad Shohel Rana Siddiki ${ }^{1}$ and Md. Harun-urRashid $^{1}$

${ }^{1}$ Department of Dairy Science, Bangladesh Agricultural University, Mymensingh, Bangladesh

${ }^{2}$ Agriculture and Environment Division, Bangladesh Academy for Rural Development (BARD), Cumilla, Bangladesh

${ }^{3}$ Department of Animal Nutrition, Bangladesh Agricultural University, Mymensingh, Bangladesh

${ }^{4}$ Department of Livestock Services, Ministry of Fisheries and Livestock, Government of the People's Republic of Bangladesh, Dhaka, Bangladesh

${ }^{5}$ Bangladesh Institute of Research and Training on Applied Nutrition (BIRTAN), Ministry of Agriculture, Government of the People's Republic of Bangladesh, Dhaka, Bangladesh

*Corresponding author: Rezaul Mahmud Nahid, Department of Dairy Science, Bangladesh Agricultural University, Mymensingh, Bangladesh. E-mail: nahidbau28@gmail.com

Received: 11 July 2020/Accepted: 20 August 2020/ Published: 31 August 2020

\begin{abstract}
Dairy calves must be fed appropriately to meet their nutritional needs, supporting optimal growth and development to achieve the recommended target age at first calving (AFC) of 24 months. Traditional restricted milk feeding practices suppress growth, contribute to negative welfare states and may result in malnutrition and immunosuppression. In this study a total of eight high yielding calves (four Holstein Friesian and four Sahiwal breed) whose average body weight was $44.8 \mathrm{~kg}$ and $58 \mathrm{~kg}$ respectively. The supplied calf starter was composed of maize crushed, rice polish, wheat bran, gram broken, mustard oil cake, vitamin mineral premix, molasses and common salt. Calf starter was supplied initially $0.25 \mathrm{~kg} / \mathrm{day} / \mathrm{calf}$ in equal halves to the experimental calves twice a day i.e. at 7.00 AM and 12.30 PM and gradually increase upto $1 \mathrm{~kg} / \mathrm{d} / \mathrm{calf}$. Average body weight gain, wither height gain, body length gain, barrel height gain, and hip height gain in Sahiwal and Holstein Friesian calves were $65.97 \pm 1.04 \mathrm{Kg}, 31.04 \pm 1.13 \mathrm{inch}, 32.34 \pm 1.46 \mathrm{inch}, 12.80 \pm 0.71 \mathrm{inch}, 35.05 \pm 1.27 \mathrm{inch}$, and $53.61 \pm 2.41 \mathrm{Kg}$, $29.78 \pm 1.17$ inch, $30.93 \pm 1.66$ inch $11.78 \pm 0.66$ inch, $33.44 \pm 1.41$ inch respectively. Our study concluded to establish a consensus on calf feeding standards which support physiological function, facilitate weaning, support growth targets and ensure calf health and welfare is protected.
\end{abstract}

Keywords: dairy calf feeding; health; nutrition; calf starter

\section{Introduction}

Dairy calves must be fed appropriately to meet their nutritional needs for optimal growth and development. Diet must also support and reflect the development of calves' digestive function from the liquid-fed pre-ruminant phase through the transition into a functional ruminant (Drackley, 2008). There are also financial implications since milk feeding accounts for $40 \%$ of total rearing costs from birth to weaning, the most expensive phase of rearing replacement dairy heifers (Boulton et al., 2017). Calf growth rates at least partly determine their age at first calving (AFC), with heifers calving at 23-24 months being more cost-efficient than later calving animals (Palczynski et al., 2020). The recommended target AFC of 24 months achieves optimal economic efficiency resulting from increased lifetime fertility, survival and milk production compared to later calving heifers (Wathes et al., 2014; Eastham et al., 2018). 
A typical Holstein-type heifer must maintain a growth rate of about $750 \mathrm{~g} /$ day from birth to achieve adequate body weight and stature to calve at 24 months (Wathes et al., 2014). Traditional feeding practices provide daily milk allowances of approximately $10 \%$ of calf bodyweight, primarily to increase solid-feed intakes to facilitate rumen development for earlier weaning. These restricted feeding practices limit the growth potential of calves (Godden et al., 2005) and are likely to provide insufficient energy in temperatures below $15^{\circ} \mathrm{C}$ (Ollivett et al., 2012). When calves are malnourished, particularly in cases of insufficient energy intakes, their immunity is impaired and they are more susceptible to disease (Gerbert et al., 2018). The effect of feeding higher planes of nutrition, above maintenance requirements, on the immunocompetence of calves is less clear cut as intensive milk feeding does not appear to affect the health and immune status of calves in a consistent manner (Hengst $e t$ al., 2012).

If a significant amount of starter or grain is consumed by the calf each day, the digestive system (rumen) will developed about 3 weeks with microbial population and enough absorptive capacity to allow the calf to continue normal growth after weaning (Hill et al., 2013). Competition for milk exists between calf and human although milk is complete food for calf and human being and it is good source of Ca, Vita-A, D, E, thiamine, riboflavin and many essential amino acids. Huge Milk deficiency of Bangladesh is about 99.23 lakh metric ton (Sarker $e t$ al., 2015; DLS, 2019) per year. In a country like Bangladesh, when milk production is very low, calf usually gets poor amount or even no allowance of milk from its dam. Therefore, feeding of dry concentrate is essential for the optimum growth and development of calves (Bahashwan and Alfadli, 2016). It can be used instead of raw milk in calf rearing to avoid human competition for milk. Moreover, calves become more susceptible to the various diseases due to the inadequate and imbalanced feed result in unable to reach optimum production level especially in a country like Bangladesh. Proper feeding may improves the performances of heifer. Due to inadequate nutrition heifer rearing period and sexual maturity becomes extended (Le-Cozler et al., 2008; Diaz et al., 2001; Bhuiyan et al., 2007) reported that feeding milk and milk replacer may be counterproductive to early weaning if more milk and milk replacer have been fed to calves (Cowles et al., 2006; Hossen et al., 2012). So this study was therefore adopted to fill in this gap, with the objectives of evaluating the effects of calf starter on growth and development of dairy calves.

\section{Materials and Methods}

\subsection{Experimental site and duration}

The experiment was conducted at Bangladesh Agricultural University Dairy Farm and Department of Dairy Science, Bangladesh Agricultural University (BAU), Mymensingh during $4^{\text {th }}$ July to $31^{\text {th }}$ December, 2017 of which first 10 days were adjustment period.

\subsection{Experimental calves' management}

Eight crossbred calf (HF and Sahiwal crossbred) were selected for the experimental purpose from BAU dairy farm. Calves were average 40 days old and the average body weight of group A (Holstein Friesian-HF) and group B (Sahiwal-SS) was $44.8 \mathrm{~kg}$ and $58 \mathrm{~kg}$ respectively. Each calf was allotted with concrete floor stall, manger and water trough in a calf barn with well-ventilation and good sanitary conditions were maintained in the barn to keep the calf comfortable throughout the study period. The animals were previously vaccinated for the infectious disease as per the vaccination schedule of the farm.

\subsection{Collection of feed ingredients}

Feed ingredients such as rice polish, wheat bran, mustard oil cake, vitamin mineral premix, molasses and common salt were purchased from local market of Mymensingh. Para and German grasses were supplied from the fodder field of BAU dairy farm.

\subsection{Preparation of calf starter}

The calf starter was composed of maize crushed, rice polish, wheat bran, gram broken, mustard oil cake, vitamin mineral premix, molasses and common salt (Table 1). Before mixing of mustard oil cake it was grounded by a milling machine. Hand mixing was done for the preparation of calf starter. All ingredients were mixed as much uniformly as possible. 
Table 1. Composition of feed ingredients (concentrates feed) supplied to the experimental calf.

\begin{tabular}{|l|l|}
\hline Ingredients & Amount of ingredients $\mathbf{( K g})$ \\
\hline Maize crushed & 2.50 \\
\hline Wheat bran & 2.80 \\
\hline Rice polish & 1.00 \\
\hline Gram broken & 1.00 \\
\hline Mustard oilcake & 2.00 \\
\hline Molasses & 0.60 \\
\hline Vitamin-mineral premix & 0.05 \\
\hline Salt & 0.10 \\
\hline Total & 10.00 \\
\hline
\end{tabular}

\subsection{Management of the experimental calf}

During the experimental period all animals were properly housed and regular cleaning was performed. Regular inspection of farm veterinary assistant was also made for the better health management.

A preliminary period of ten days was observed to adjust the calves with the experimental ration. Calf starter was supplied initially $0.25 \mathrm{~kg} / \mathrm{day} / \mathrm{calf}$ in equal halves to the experimental calves twice a day i.e. at $7.00 \mathrm{AM}$ and $12.30 \mathrm{PM}$ and gradually increase upto $1 \mathrm{~kg} / \mathrm{d} / \mathrm{calf}$. Green grasses were supplied ad libitum at $1.00 \mathrm{PM}$ to the respective group of calves. All the calves had free access to the clean normal fresh drinking water for 24 hours.

\subsection{Data analysis}

The computer program student's " $t$ " test calf starter was used for the analysis by Microsoft Excel 2010. It was done to find out the interaction of body weight gain, body length gain, wither height gain, hip height gain and heart girth gain of dairy calves.

\section{Results and Discussion}

The experiment was conducted up to 17 weeks and the entire experimental period resultant average total Body weight gain, Wither height gain, Barrel height gain and Hip height gain are shown in Table 2.

Table 2. The mean value with its standard error of BWG, WHG, BHG and HHG of dairy calf at different treatment over the period of experiment.

\begin{tabular}{|l|l|l|l|l|}
\hline Parameters & Group HF & Group SS & p-value & Level of sig. \\
\hline BWG $(\mathrm{Kg} / 17 \mathrm{w})$ & $53.61 \pm 2.41$ & $65.97 \pm 1.04$ & $<0.0001$ & $* * * *$ \\
\hline WHG (inch/17w) & $29.78 \pm 1.17$ & $31.04 \pm 1.13$ & 0.0032 & $* *$ \\
\hline BLG (inch/17w) & $30.93 \pm 1.66$ & $32.34 \pm 1.46$ & 0.0134 & $*$ \\
\hline BHG (inch $/ 17 \mathrm{w})$ & $11.78 \pm 0.66$ & $12.80 \pm 0.71$ & 0.0002 & $* * *$ \\
\hline HHG (inch $/ 17 \mathrm{w})$ & $33.44 \pm 1.41$ & $35.05 \pm 1.27$ & 0.0040 & $* *$ \\
\hline
\end{tabular}

*indicates significant at $5 \%$ level of probability, ** indicates significant at $1 \%$ level of probability and NS indicates nonsignificant effect on the parameter. $\mathrm{BWG}=$ body weight gain, $\mathrm{WHG}=$ wither height gain, $\mathrm{BLG}=$ body length gain, $\mathrm{BHG}=$ barrel height gain, $\mathrm{HHG}=$ hip height gain.

Calf weight gain depends on the diet fed, and it also affects age at puberty, endocrine parameters, and ovarian structures. Throughout the experiment period the average total body weight gain (BWG) was found $53.61 \pm 2.41$ $\mathrm{kg}$ and $65.97 \pm 1.04 \mathrm{~kg}$ in group HF and group SS respectively. Feed intake is positively associated with body weight gain of heifers (Lents et al., 2005). Shamay et al., (2005) also reported that feeding grass hay supplemented with protein concentrate to heifers improved average BWG. Present research result indicates that average total BWG was significantly $(\mathrm{p}>0.0001)$ higher in group SS than the group HF this may be due to increase calf starter or improved associative action of nutrients or improved digestibility of feed (Eastham et al., 2018). These result is also agreed to (Darshan et al., 2007; Talukder et al., 2017) who found that the body weight of calves throughout the experimental period increased due to the increase calf starter or improved associative action of nutrient or improved digestibility.

The wither height gain (WHG) of crossbred calf is found 29.78 \pm 1.17 inch and 31.04 \pm 1.13 inch in group HF and group SS respectively which differ significantly at $(\mathrm{p}<0.0032)$; which is similar to the result of Wathes $e$ al. 
(2014). In the present study the wither height is increased in group SS, this may be the cause of protein supplementation, more calf starter intake and efficient utilization of feed.

From the experiment, there was a significant effect of calf starter on body length gain. The body length increased at $1 \%$ level of significant. The highest body length was found in group SS which was $32.34 \pm 1.46$ inch than the group HF $30.93 \pm 1.66$ inch. The result of present study is similar with the result of Boulton et al. (2017) reported that increased body length with the increase of protein concentrates.

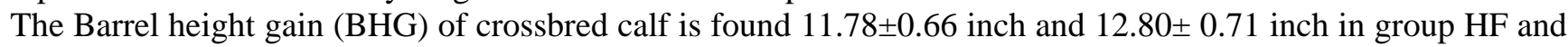
group SS respectively which differ significantly at ( $\mathrm{p}<0.0002)$. Which is similar to the result of Palczynski et al. (2020) which found that the wither height of Japanese Black cattle increased steadily. In the present study the wither height is increased in group SS, this may be the cause of calf starter intake and efficient utilization of feed.

In this experiment the average mean value indicates that hip height gain (HHG) was highest in group SS and there is a significant $(\mathrm{p}<0.05)$ difference present with the group HF. This result may be due to feeding of calf starter along with green grass. According to Gerbert et al., (2018).that the hip height gain of Holstein heifers was smaller $(\mathrm{p}<0.001)$ fed straw based diet than the heifers fed protein concentrate along with green grass and various types of hay.

\section{Conclusions}

The result of the study suggest that supplementation of calf starter with green grass be the important in calf feeding in relation to reproduction and nutritional status; especially those are kept for herd replacement. Calf starter should be fed to the dairy calf from the very early life when its digestive physiology develops enough to utilize this feed will end with a good result provided that there is no interrupted feeding and growth in the previous life.

\section{Conflict of interest}

None to declare.

\section{References}

Bahashwan S and S Alfadli, 2016. Dam weight, udder score and body condition score effect on calf birth weight and preweaning daily gain in Dhofari cattle breed. Livest. Res. Rural. Dev., 28: 41.

Bhuiyan AKFH, MM Hossain and GK Deb, 2007. Indigenous cattle genetic resources of Bangladesh and a way forward to their development. Ban. J. Prog. Sci. Tech., 5: 105-112.

Boulton AC, J Rushton and DC Wathes, 2017. An empirical analysis of the cost of rearing dairy heifers from birth to first calving and the time taken to repay these costs. Animal, 11: 1372-1380.

Cowles MH and M Cheesbrough, 2006. District laboratory practice in tropical countries, Cambridg University press, Cambridge. pp. 355-358.

Diaz MC, ME Van Amburgh, JM Smith, JM Kelsey and EL Hutten. 2001. Composition of growth of Holstein calves fed milk replacer from birth to 105-kilogram body weight. J. Dairy Sci., 84: 830-842.

DLS, 2019. Annual Progress Report. Department of Livestock Services., Farm gate, Dhaka.

Drackley JK, 2008. Calf Nutrition from Birth to Breeding. Vet. Clin. N. Am. Food Anim. Pract., 24: 55-86.

Eastham NT, A Coates, P Cripps, H Richardson, R Smith and G Oikonomou, 2018. Associations between age at first calving and subsequent lactation performance in UK Holstein and Holstein-Friesian dairy cows. PLoS ONE, 13: e0197764.

Gerbert C, D Frieten, C Koch, G Dusel, K Eder, T Stefaniak, J Bajzert, P Jawor and A Tuchscherer, 2018. Effects of ad libitum milk replacer feeding and butyrate supplementation on behavior, immune status, and health of Holstein calves in the postnatal period. J. Dairy Sci., 101: 7348-7360.

Godden SM, JP Fetrow, JM Feirtag, LR Green and SJ Wells, 2005. Economic analysis of feeding pasteurized nonsaleable milk versus conventional milk replacer to dairy calves. J. Am. Vet. Med. Assoc., 226: 15471554.

Hengst BA, LM Nemec, RR Rastani and TF Gressley, 2012. Effect of conventional and intensified milk replacer feeding programs on performance, vaccination response, and neutrophil mRNA levels of Holstein calves. J. Dairy Sci., 95: 5182-5193.

Hill TM, HG Bateman, JD Quigley, JM Aldrich, RL Schlotterbeck and AJ Heinrichs, 2013. REVIEW: New information on the protein requirements and diet formulation for dairy calves and heifers since the Dairy NRC 2001. Prof. Anim. Sci., 29: 199-207. 
Hossen MS, SS Hossain, AKFH Bhuiyan, MA Hoque and MAS Talukder, 2012. Comparison of some important dairy traits of crossbred cows at Baghabarighat milk shed area of Bangladesh. Ban. J. Anim. Sci., 41: 13-18.

Le-Cozler Y, V Lollivierm, P Lacasse and C Disenhaus, 2008. Rearing strategy and optimizing first-calving targets in dairy heifers: A review of animal 2: 1393- 1404.

Lents CA, RP Wetteman, FJ White, I Rubio, NH Ciccioli, LJ Spicer, DH Keisler and ME Payton, 2005. Influence of nutrient intake and body fat on concentrations of insulin-like growth factor-I, insulin, thyroxine, and leptin in plasma of gestating beef cows. J. Anim. Sci, 83: 586- 596.

Ollivett TL, DV Nydam, TC Linden, DD Bowman and ME Van Amburgh, 2012. Effect of nutritional plane on health and performance in dairy calves after experimental infection with Cryptosporidium parvum. J. Am. Vet. Med. Assoc., 241: 1514-1520.

Palczynski LJ, ECL Bleach, ML Brennan and PA Robinson, 2020. Appropriate Dairy Calf Feeding from Birth to Weaning: "It's an Investment for the Future". Animals, 10: 116.

Sarker YA, AH Miah, N Sharif, MH Himel, S Islam, RC Ray, TK Paul, MT Islam and MH Sikder, 2015. A retrospective study of common diseases at Veterinary Teaching Hospital, Bangladesh Agricultural University, Mymensingh. Bangl. J. Vet. Med., 13: 55-61.

Shamay A, D Werner, U Moallem, H Barash and I Bruckental, 2005. Effect of Nursing Management and Skeletal Size at Weaning on Puberty, Skeletal Growth Rate, and Milk Production during First Lactation of Dairy Heifers. J. Dairy Sci., 44: 1460-1469.

Talukder MAI, M Shahjahan, MS Islam and S Munira, 2017. Diversity in morphology and pigmentation patterns of local Pabna cattle in Bangladesh. Res. Agric., Livest. Fish., 4: 201-208.

Wathes DC, GE Pollott, KF Johnson, H Richardson and JS Cooke, 2014. Heifer fertility and carry over consequences for life time production in dairy and beef cattle. Animal, 8: 91-104. 